\title{
Białoruska prasa religijna w Niemczech Zachodnich w latach 1945-1951
}

Artykuł traktuje o białoruskiej prasie religijnej (prawosławnej, katolickiej, protestanckiej) wydawanej w trzech zachodnich strefach okupacyjnych Niemiec w pierwszych latach powojennych. Wówczas w Niemczech Zachodnich mieszkała największa liczba białoruskich uchodźców wojennych. Ważnym elementem życia emigrantów była działalność religijna, w tym wydawnicza. Działalność ta wynikała z przyczyn społecznych, politycznych i narodowych. Była to niemal powszechna reakcja uchodźców na niepewną przyszłość. Ci ludzie zostali pozbawieni swojej ojczyzny, znaleźli się w obcym środowisku kulturowym, bez możliwości wpływania na własny los, całkowicie na łasce innych. W tej sytuacji ich smutki, zmartwienia i obawy wyrażano na papierze. Tym czasem spory polityczne między powojennymi białoruskimi emigrantami przyczyniły się do intensyfikacji działalności wydawniczej. Działalność wydawnicza służyła również zachowaniu tożsamości narodowej emigrantów i szerzeniu wśród nich wartości narodowych i patriotycznych (zwłaszcza wśród młodzieży).

Słowa kluczowe: diaspora białoruska, Niemcy Zachodnie, religia, prasa

Po zakończeniu II wojny światowej na terenie trzech zachodnich stref okupacji Niemiec i Austrii oraz we Włoszech znajdowało się ok. 1 mln uchodźców z Europy Wschodniej, którzy z rozmaitych względów odmawiali powrotu do domu. Według źródeł alianckich w latach 1947-1951 w obozach DP przebywało 5147 Białorusinów. Natomiast 
historycy białoruscy twierdzą, że rzeczywista liczba uchodźców białoruskich była znacznie większa i wynosiła 60-100 tys. ludzi1. Niezależnie od tego, ilu było Białorusinów w Niemczech Zachodnich, nie ulega jednak wątpliwości, że zaledwie kilka tysięcy z nich uczestniczyło w białoruskim życiu społecznym, kulturalnym oraz religijnym. Alianci zachodni wkrótce zdali sobie sprawę, że rzesza ludzi nie zamierza wracać do swych krajów, które znalazły się pod panowaniem komunistycznym. Zachodziła więc konieczność organizacji tymczasowego pobytu dla tych ludzi, którzy otrzymali status dipisów, czyli osób przemieszczonych (Displaced Persons). Ciężar organizacji obozów dla dipisów spoczął wówczas na Dowództwie Naczelnym Sił Ekspedycyjnych Aliantów. 25 listopada 1945 r. doszło do zawarcia porozumienia pomiędzy nim i Administracją Narodów Zjednoczonych do Spraw Pomocy i Odbudowy (United Nations Relief and Rehabilitation Administration - UNRRA) w sprawie opieki nad uchodźcami. Od 1947 r. opiekę nad dipisami przejęła Międzynarodowa Organizacja Uchodźców (IRO). Aby zaspokoić potrzeby uchodźców różnych narodowości, zdecydowano, że obozy DP będą tworzone według klucza narodowościowego (czy raczej kraju pochodzenia). W obozach utworzono samorząd (wybierano radę obozową) i służbę porządkową, które rekrutowały się spośród mieszkańców. W gestii tych instytucji znajdowały się niemalże wszystkie sprawy wewnętrzne. Alianci jedynie ingerowali w sytuacjach szczególnych, kiedy samorząd nie radził sobie z problemami. Alianci podejmowali również decyzje $\mathrm{w}$ kwestii rozwiązania lub przeniesienia obozów. Na skutek wyodrębnienia uchodźców narodowości białoruskiej spośród innych narodowości w strefie amerykańskiej powstały następujące obozy białoruskie: w czerwcu 1945 r. w Ratyzbonie (w lipcu 1946 obóz ten został przeniesiony do miejscowości Michelsdorf), jesienią

${ }^{1}$ Н. Гардзіенка, Беларусы ў Вялікабрытаніi, Мінск 2010, с. 60; Белорусские остарбайтеры. Историко-аналитическое исследование, Минск 2001, с. 288; Instytut Polski i Muzeum im. gen. Sikorskiego, Białoruskie uchodźstwo niepodległościowe, sygn.: A.11E.1110. 
1946 r. w Osterheim, zaś w maju 1947 r. - w Windischbergdorf. Latem 1949 r. uchodźcy białoruscy w strefie amerykańskiej zostali skoncentrowani w większych obozach w miejscowościach Rosenheim, Backnang, a także w mniejszym w Mittenwald. Tymczasem w strefie brytyjskiej powstał największy obóz białoruski w Niemczech - w miejscowości Watenschtedt. Ogółem w latach 1945-1950 przez ten obóz przewinęło się 1420 ludzi².

Obozy i grupy białoruskie zamieniły się w prawdziwe ogniwa życia białoruskiego na emigracji. Zakładano parafie, przedszkola, szkoły podstawowe i średnie, zespoły artystyczne, drużyny sportowe, organizacje zawodowe, stowarzyszenia kombatanckie, wydawano gazety i czasopisma. Ponadto rozwijał się ruch skautowski i studencki. W obozach białoruskich obchodzono również święta narodowe i religijne. Wszystko to miało służyć utrwaleniu tradycji narodowej oraz pielęgnowaniu jej z pokolenia na pokolenie. Wśród organizacji zawodowych i środowiskowych można wymienić m.in. organizacje kobiet, lekarzy, nauczycieli, dziennikarzy ${ }^{3}$.

Pokłosiem działalności wspomnianych stowarzyszeń było powstanie w obozach dipisów w Niemczech bogatego dorobku literackiego, publicystycznego i wydawniczego, który nie ma analogii w dziejach całej powojennej emigracji białoruskiej w innych krajach świata. Analiza dostępnych źródeł pozwala wysnuć tezę, że podjęcie aktywności wydawniczej miało trzy główne przyczyny o charakterze społeczno-kulturowym, które najogólniej można scharakteryzować jako: społeczno-bytowe, polityczno-ideowe i narodowo-ideologiczne. Działalność ta była niewątpliwie odpowiedzią na niemal powszechną w obozach frustrację panującą wśród uchodźców w obliczu niepewnej przyszłości. Ci ludzie zostali pozbawieni ojczyzny, znaleźli się w obcym kulturowo otocze-

2 Я. Максімюк, Беларуская гімназія імя Янкі Купаль ў Заходняй Нямеччыне 1945-1950, New York, Białystok 1994, c. 20-42.

${ }^{3}$ Zob.: J. Grzybowski, Pogoń między Ortem Białym, Swastyka i Czerwona Gwiazda. Białoruski ruch niepodległościowy w latach 1939-1956, Warszawa 2011, s. 575-678. 
niu bez możliwości wpływu na własny los, całkowicie zdani na łaskę innych. W zaistniałej sytuacji przelewano na papier własne smutki i troski, dawano wyraz własnym niepokojom. Działalność wydawnicza i literacka służyła w końcu zachowaniu tożsamości narodowej emigrantów oraz krzewieniu wśród nich (zwłaszcza wśród młodzieży) wartości narodowych i patriotycznych. Ponadto do intensyfikacji aktywności wydawniczej walnie przyczynił się rozłam polityczny powojennej emigracji białoruskiej - na zwolenników Rady Białoruskiej Republiki Ludowej (BRL) i Białoruskiej Centralnej Rady (BCR). Zapoczątkował on burzliwą polemikę pomiędzy przedstawicielami dwóch wrogich sobie obozów. Efektem tej polemiki są liczne teksty o charakterze literackim i publicystycznym (ulotki, paszkwile, pamflety, eseje) pojawiające się w obozach DP w latach 1945-1951.

Nieodłącznym elementem aktywności wydawniczej było wydawanie własnych periodyków (czasopism, gazet) o charakterze społeczno-politycznym, kulturalnym i innym. W danej publikacji skupimy się na analizie prasy białoruskiej, która w zamyśle jej wydawców miała charakter religijny. W omawianym okresie w Niemczech ukazywało się kilka białoruskich tytułów prasowych, na łamach których dominowała tematyka religijna. Obecnie te periodyki są przechowywane w bibliotekach w Londynie, Nowym Jorku i Mińsku.

Zanim przejdziemy jednak do omawiania poszczególnych tytułów powinno się zwrócić uwagę na fakt, iż dzieje religijne emigracji białoruskiej po 1945 r. były bardzo złożone i obfitowały w rozmaite perypetie. Większość emigrantów pochodziła z rodzin tradycyjnych i wykazywała silne przywiązanie do religii. W warunkach emigracji wrażliwość religijna uległa jeszcze większemu nasileniu. Ludzie znajdowali się z dala od rodzimych stron, byli pozbawieni ojczyzny i niepewni swego losu, musieli więc szukać pocieszenia i ratunku. Ponadto w przypadku znacznej części uchodźców Białorusinów religia była istotnym elementem podtrzymania tożsamości narodowej.

Pod względem wyznaniowym przeważną większość emigrantów stanowili wyznawcy prawosławia (ponad 80\%). Już od pierwszych dni 
istnienia obozów białoruskich powstawały w nich parafie prawosławne. Najbardziej znaną parafią była parafia pod wezwaniem Św. Eufrozyny Połockiej w Ratyzbonie, gdzie proboszczem był ks. Mikałaj Łapicki, absolwent teologii prawosławnej na Uniwersytecie Warszawskim. Duchowny ten po wojnie dał się poznać jako gorliwy duszpasterz Białorusinów na obczyźnie. Oprócz obozu w Ratyzbonie w 1945 r. powstały parafie w innych obozach białoruskich DP. W Watenstedt świątynię urządzono w drewnianym baraku obozowym. Posługę kapłańską w tej parafii pełnili ks. Surwiłło i ks. Smirnow ${ }^{4}$. W obozie białoruskim w Goslar wierni nie posiadali świątyni, lecz od czasu do czasu nabożeństwa urządzał ksiądz, którzy przyjeżdżał z Watenstedt. W 1945 r. powstała również parafia w obozie Warberg ${ }^{5}$. Brak środków poważnie utrudniał organizację parafii i zaopatrzenie ich w odpowiedni wystrój i utensylia. Do tego dochodziły wewnętrzne nieporozumienia i spory, którymi było nękane nieliczne środowisko białoruskie. Faktem jest, że powojenne białoruskie prawosławie na emigracji było dotknięte podziałami. Opiekę duszpasterską nad uchodźcami sprawowali hierarchowie Białoruskiej Cerkwi Prawosławnej, którzy ewakuowali się latem 1944 roku z Białorusi na zachód, a po kapitulacji Niemiec podzielili los pozostałych uchodźców białoruskich. Kanoniczny status białoruskiego prawosławia na emigracji był nieuregulowany. W maju 1946 roku biskupi białoruscy (abp Pantelejmon, biskupi: Benedykt, Atanazy, Filoteusz i Grzegorz) zrzekli się swoich dotychczasowych stanowisk i przeszli pod jurysdykcję Rosyjskiej Cerkwi Prawosławnej za Granicą. Tym samym prawosławni emigranci narodowości białoruskiej znaleźli się w jurysdykcji hierarchów rosyjskich. Powstała Metropolia Białoruska Rosyjskiej Cerkwi Prawosławnej za Granicą. Przejście biskupów pod skrzydła Cerkwi rosyjskiej wbrew pozorom nie oznaczało likwidacji białoruskiej autonomii religijnej, ponieważ hierarchowie białoruscy zachowali pewną

${ }^{4}$ А. Вініцкі, Матэрыялы да гісторыі беларускай эмігращыі ў Нямеччыне у 1939-1951 гадох. Ч. 2. Рэлігійныя справы, Los Angeles 1968, с. 5.

${ }^{5}$ Ibidem. 
samodzielność w sprawach wewnętrznych. Wszakże część wiernych narodowości białoruskiej nigdy nie zaakceptowała tej zmiany i uznała czyn biskupów białoruskich za ewidentną zdradę. W związku z powyższym w 1948 r. przy wsparciu duchowieństwa Ukraińskiej Autokefalicznej Cerkwi Prawosławnej (UACP) doszło do utworzenia Białoruskiej Autokefalicznej Cerkwi Prawosławnej (BACP), na uchodźstwie z metropolitą Sergiuszem (Ochotenko) na czele. Należy zaznaczyć, że powołanie BACP nastąpiło z pominięciem drogi kanonicznej, co naraziło wiernych i duchowieństwo tej Cerkwi na zarzuty o niekanoniczności. Część wiernych konsekwentnie odrzucało BACP, uznając ją za „fikcję”. Tak więc jednolite do tej pory środowisko prawosławnych Białorusinów na emigracji doznało rozłamu na ,autokefalistów” i ,zarubieżników” (od nazwy „zarubieżnej” Rosyjskiej Cerkwi Prawosławnej). Wbrew pozorom u źródeł tego rozłamu nie leżały względy religijne, lecz stricto polityczne i ambicjonalne. Rzeczywistym źródłem nieporozumień była rywalizacja pomiędzy dwoma wspomnianymi wcześniej emigracyjnymi ośrodkami władzy politycznej - Radą Białoruskiej Republiki Ludowej (wspierającą autokefalistów) i Białoruską Centralną Radą. Owe nieporozumienia sprawiły, że przez jakiś czas zapanowała dezorganizacja i zamęt w życiu religijnym Białorusinów. Odcisnęło to też trwałe piętno na dalszej historii emigracji białoruskiej6 .

Paradoksalnie, wspomniane wcześniej nieporozumienia wśród prawosławnych Białorusinów przyczyniły się do pojawienia się pierwszego białoruskiego periodyku religijnego na emigracji. 5 maja $1946 \mathrm{r}$. w Ratyzbonie zwołano I zjazd Białorusinów prawosławnych ze wszystkich trzech stref okupacyjnych, na który przybyło 136 delegatów ${ }^{7}$. Wówczas powołano Białoruskie Zrzeszenie Prawosławne mające na

${ }^{6}$ J. Grzybowski, M. Grzybowska, Białoruska Autokefaliczna Cerkiew Prawosławna na emigracji i udział w jej działalności duchowieństwa ukraińskiego, «Наукові записки Національного університету „Острозька академія”. Серія „Історічні науки"» 2013, вип. 20, с. 239-245.

${ }^{7}$ Ю. Гарбінскі, Беларускі рэлігійны друк на Захадзе, 1945-2005, New York, Warszawa 2009, c. 171. 
celu zaspokoić potrzeby religijne i narodowe dipisów. Delegaci wyrazili swój sprzeciw wobec działań hierarchów białoruskich zmierzających do przyłączenia się do emigracyjnej Cerkwi rosyjskiej. Wówczas podjęto również decyzję o wydawaniu czasopisma dla prawosławnych Białorusinów mającego być organem wspomnianego zrzeszenia. Pierwszym periodykiem białoruskim ukazującym się na ziemi niemieckiej i poświęconym sprawom religijnym był miesięcznik «Зьвіняць званы Сьвятой Сафіi. Часопіс праваслаўных беларусаў» (Dzwonia Dzwony św. Zofii. Czasopismo Prawosławnych Białorusinów). Nazwa nawiązywała do Soboru Sofijskiego, czyli Bazyliki Mądrości Bożej w Połocku, zbudowanej w XI wieku. Redaktorem naczelnym został Jurka Vićbič vel Jury Stukalič (właściwe: Sierafim Ščarbakoŭ), znany działacz społeczny i religijny, więzień łagrów stalinowskich, wybitny publicysta, pisarz i dziennikarz. Pierwszy numer tego czasopisma ukazał się w lutym 1946 r. w Ratyzbonie. Choć czasopismo miało być organem Białoruskiego Zrzeszenia Prawosławnego, w rzeczywistości odzwierciedlało poglądy i intencje redaktora. Świadczy o tym fakt, że kiedy jesienią 1946 r. Białoruskie Zrzeszenie Prawosławne zaakceptowało decyzję biskupów o poddaniu się jurysdykcji Cerkwi rosyjskiej, to jednak dotychczasowa białoruska i niepodległościowa linia pisma nie uległa zmianie. Vićbič postulował konieczność przywrócenia białoruskiemu prawosławiu cech narodowo białoruskich. Autor dał temu wyraz w artykule „Białoruska Cerkiew Prawosławna powinna być narodowa”, w którym czytamy m.in.: „Cerkiew Prawosławna przystąpiła do pełnego odrodzenia i zwrotu do swej niegdysiejszej białoruskości. Prawosławna Cerkiew na Białorusi musi zostać białoruską, a wiara prawosławna - narodową"».

Jurka Vićbič opowiadał się za białorutenizacją życia cerkiewnego, lecz drogą pokojowej ewolucji. W związku z tym nie darzył on szacunkiem autokefalistów, którzy - jego zdaniem - wybrali „drogę na skróty". Redaktor wyrażał przekonanie, że białorutenizacja Cerkwi jest

${ }^{8}$ В-а, Беларуская Праваслаўная Царква павінна быцъь нацььянальнай, «Зьвіняць званы Сьвятой Сафіi» 1946, № 3, с. 28. 
kwestią czasu. Apelował o zbliżenie hierarchów do narodu w celu budowania wspólnego niezależnego bytu narodowego. W artykule „Cerkiew i Naród" twierdził, że cerkiewna hierarchia i duchowieństwo powinny być mianowane zgodnie $\mathrm{z}$ wolą wiernych, bo w przeciwnym razie cerkiew i społeczeństwo będą sobie obce. Autor pisał m.in.: „Trzeba, żeby duchowieństwo było bliskie wiernym duchowo, żeby było dla nich swoje, tworzyło z nimi jedność. Tylko wówczas zapanuje zgoda między państwem i cerkwią narodu, gdy mężowie stanu i cerkiewni hierarchowie będą sobie bliscy. [...] Każdy naród pragnący pokoju i współpracy między Cerkwią i państwem, między duchem i ciałem narodu, dąży do uczynienia cerkwi narodową. $Z$ cerkiewnego punktu widzenia unarodowienie duchowieństwa tam, gdzie ono z jakichś przyczyn nie jest narodowe, traktuje się jako czyn na rzecz wiary"'.

Tego poglądu Vićbič konsekwentnie bronił na łamach swojego czasopisma. Zamieszczane na łamach wydania materiały były przepojone głęboką fascynacją kulturą białoruską i wiarą prawosławną, co - zdaniem redaktora - tworzyło nieodłączną całość. Vićbič obstawał przy poglądzie, że prawosławie idealnie odpowiada psychice i kulturze Białorusinów. Twierdził, że nikt jeszcze nie zdołał oddzielić historii prawosławia od historii narodu białoruskiego. Jednocześnie nie szukał konfrontacji z innymi wyznaniami. Wszystkie publikacje cechował daleko idący umiar w wypowiedziach i ocenach oraz tolerancja. Na ogół można odnieść wrażenie, że celem redaktora było w dużej mierze uspokojenie nastrojów wśród emigrantów po burzliwych wydarzeniach związanych z odejściem biskupów do Cerkwi rosyjskiej. Na łamach pisma zamieszczano szczegółowo kronikę białoruskiego życia prawosławnego na emigracji. W dziale „Kronika” informowano na bieżąco o wydarzeniach, które zaszły w życiu dipisów białoruskich ze szczególnym uwzględnieniem spraw prawosławnych. Tak na przykład na łamach periodyku znalazły swoje odbicie desperackie zmagania dipisów białoruskich o utrzymanie własnej organizacji cerkiewnej w związku z przejściem

${ }^{9}$ Idem, Царква і Народ, «Зьвіняць званы Сьвятой Сафіi» 1946, № 3, с. 29. 
hierarchów białoruskich w jurysdykcję Cerkwi rosyjskiej ${ }^{10}$. Z upływem czasu potępienie biskupów jako zdrady ustąpiło jednak miejsca zrozumieniu dla decyzji hierarchów. Zwłaszcza daje się to zauważyć od września 1946 r., kiedy to w Ratyzbonie odbył się II zjazd prawosławnych Białorusinów, na którym poparto decyzję biskupów o przejściu w jurysdykcję Cerkwi rosyjskiej. Wkrótce większość społeczności białoruskiej uznało decyzję hierarchów. Od tamtego czasu redakcja czasopisma przestała potępiać biskupów. Niemniej czasopismo w dalszym ciągu było utrzymywane w duchu narodowo-białoruskim, a problematyka patriotyczna na jego łamach była mocno wyeksponowana ${ }^{11}$.

$\mathrm{Na}$ łamach miesięcznika niekiedy podnoszono również problematykę dotyczącą relacji międzywyznaniowych. Wypowiadano się np. na temat unii kościelnej. Pod tym względem czasopismo niczym się nie różniło od innych periodyków prawosławnych, krytykując unię brzeską $1596 \mathrm{r}$. Ponadto piętnowano wszelkie próby restytucji obrządku wschodniego wśród emigrantów białoruskich. Odnoszono się również do spraw innych niż religijne. Tak na przykład nie mógł ujść uwadze redakcji spór o nazwę ojczystego kraju. Cześć emigrantów (przede wszystkim Jan Stankievič) propagowało nazwę „Krywija” zamiast „Białoruś”. Wydawcy miesięcznika definitywnie odrzucali tę nazwę i negowali jej zasadność $^{12}$. Redakcja nie ograniczała się do tematów stricto białoruskich. Informowano czytelników o aktualnych wydarzeniach zachodzących w światowej polityce. Śledzono informację o sytuacji religii w Związku Sowieckim. Na łamach czasopisma nie brakowało również publikacji literackich (utwory literatów białoruskich m.in. Maksyma Bohdanowicza, Janki Kupały, Masieja Siadnioŭa, Alaksieja Sałavieja, Janki Zołaka). Korzystając z faktu, że Jurka Vićbič należał do stowarzyszenia

10 Зварот беларускай грамадзкасьиі да беларускага епіскапату, «Зьвіняць званы Сьвятой Сафіi» 1946, № 4, с. 28-29.

${ }^{11}$ Селянін, У Беларускім Праваслаўным Аб’яднаньні, «Зьвіняць званы Сьвятой Сафіi») 1946, № 6, с. 35-37.

${ }^{12}$ А. Крыжаніч, Гара нарадзіла мылш, «Зьвіняць званы Сьвятой Сафіi» 1946, № 4, c. 30-32. 
literackiego „Šypšyna”, na łamach miesięcznika zamieszczano kronikę tej organizacji. Na końcu każdego numeru publikowano kalendarz cerkiewny i ludowy. Reasumując, należy stwierdzić, że «Зьвіняць званы Сьвятой Сафii» było jednym z pierwszych czasopism na emigracji, na łamach którego zaprezentowano bardzo szerokie spektrum problemów i zagadnień dotyczących nie tylko religii, lecz również polityki, literatury, kultury i historii.

Po przejściu biskupów białoruskich pod jurysdykcję Rosyjskiej Cerkwi Prawosławnej za Granicą pojawiło się jeszcze jedno pismo o charakterze religijnym, odbiorcami którego byli dipisi białoruscy. W $1949 \mathrm{r}$. wyszedł pierwszy numer czasopisma «Праваслаўны беларус» (Prawosławny Białorusin). Oficjalnie czasopismo wydawane było przez niezależną organizację społeczną Komitet Prawosławnych Chrześcijan Białorusinów. W rzeczywistości jednak czasopismo było organem prasowym metropolii białoruskiej Cerkwi rosyjskiej i znalazło się w rękach grupki nacjonalistycznie nastawionych działaczy rosyjskich. Redaktorem naczelnym został Konstanty Jakub, człowiek o bardzo wątpliwej reputacji wśród emigrantów. Nie odnalazł się on w żadnym środowisku: ani rosyjskim, ani białoruskim. Pierwszych kilka numerów ukazało się po białorusku, natomiast pozostałe wydawano wyłącznie w języku rosyjskim. Łącznie w 1949-1951 ujrzało światło dzienne trzynaście numerów. Redakcja uważała się za „zaiste białoruskie prawosławno-religijne czasopismo". W praktyce wydawcy usiłowali pod płaszczykiem promowania białoruskiego prawosławia przemycić rosyjskie idee nacjonalistyczne. Rosyjską Cerkiew Prawosławną za Granicą traktowano jako jedyną prawowitą dziedziczkę patriarcha moskiewskiego, wolną od wpływów bolszewickich, podczas gdy Cerkiew w kraju uważano za zniewolony przez satrapię komunistyczną. W odezwie Komitetu Prawosławnych Chrześcijan Białorusinów na Emigracji czytamy m.in.: „My, prawosławni Białorusini uważamy się za przynależnych do świętej Prawosławnej Rosyjskiej Cerkwi Zagranicą, ponieważ cerkiew ta jest integralną częścią naszej Rosyjskiej Cerkwi Prawosławnej, która istnieje na ojczystej ziemi ruskiej od tysiąca lat. [...] Nasza Cerkiew Prawosławna 
za Granicą nie uzna patriarchy moskiewskiego, która przeszła na służbę do władz"13.

Wątek „rosyjski” na łamach omawianego czasopisma wyeksponowano tak, że czasami można odnieść wrażenie, że ma się do czynienia nie z czasopismem hierarchii białoruskiej, lecz rosyjskiej politycznej partii o zabarwieniu ultraprawicowym. Autorzy czasopisma prezentowali rosyjskie poglądy szowinistyczne. Podkreślano więzi Białorusinów i kultury białoruskiej z narodem rosyjskim i jego kulturą. Na łamach czasopisma «Праваслаўны беларус» gościli autorzy lansujący tezę o tym, że język rosyjski na Białorusi jest językiem warstw uprzywilejowanych, podczas gdy język i kultura białoruska umiejscowione na niższym poziomie. Publikowano również artykuły wychodzące spod pióra reprezentantów nieistniejących i fikcyjnych organizacji pseudobiałoruskich (np. Białoruska Organizacja Monarchistów), które w rzeczywistości nie istniały. Na osobną uwagę zasługuje interpretacja dziejów narodu białoruskiego przez autorów i wydawców czasopisma «Праваслаўны беларус». Fakty i postacie historyczne oceniano pod kątem ich związku z prawosławiem. W związku z tym piętnowano władców Wielkiego Księstwa Litewskiego. Przedstawiano ich jako krwiożerczych satrapów żądnych krwi „ludu ruskiego”. Odrzucano białoruskie symbole narodowe (herb „Pogoń”) jako pogańskie i cudze. W zamian proponowano symbole rosyjskie jako białoruskie (sztandar św. Jerzego) ${ }^{14}$.

Wprawdzie potępiano politykę narodowościową carskiej Rosji wobec Białorusinów, lecz retoryka autorów czasopisma przypominała tą, której niegdyś używali nacjonaliści rosyjscy. Autorów tego periodyku cechowała ostra krytyka białoruskich działaczy narodowych. W szczególności na łamach czasopisma nie oszczędzano ostrych słów pod adresem „krywiczów” (zwolenników Rady BRL), których obwiniano

${ }^{13}$ Православные - Белоруссы! «Православный Белорусс» 1949, № 8, с. 1.

${ }^{14}$ Долой ненавистное знамя «Погоня», Да здравствует наше славное белое со св. Георгием Победоносием белорусское знамя, «Православный Белорусс» 1949, № 10 , c. 19 . 
m.in. o propagowanie unii kościelnej ${ }^{15}$. W związku z uznaniem „krywickiego" Białoruskiego Komitetu Narodowego przez władze IRO na strefę amerykańską, wydawcy czasopisma wzywali prawosławnych dipisów narodowości białoruskiej do sprzeciwu wobec poczynań organizacji białoruskich. 15 listopada 1949 r. redakcja czasopisma wystosowała protest do Kwatery Głównej IRO na strefę amerykańską przeciwko uznaniu przez Amerykanów wspomnianego komitetu: „Komitet krywicki jest nieliczną reprezentacją grupki zagorzałych wrogów kościoła prawosławnego i narodu białoruskiego, którzy postawili sobie za cel unicestwić życie religijne emigracji białoruskiej. [...] Uznanie komitetu krywickiego za przedstawicielstwo emigracji białoruskiej jest wielkim aktem niesprawiedliwości i krzywdy w stosunku do emigracji białoruskiej. Z całą stanowczością protestujemy przeciwko uznaniu i żądamy niezwłocznie ukarać komitet krywicki za to, że on oszukał władze IRO, udając sobie za komitet emigracji białoruskiej"16.

W mniejszym stopniu atakowano zwolenników R. Ostrowskiego i jego Białoruskiej Centralnej Rady. Aczkolwiek ten odłam białoruskiego obozu niepodległościowego również nie darzono sympatią.

Na łamach czasopisma rzucano gromy pod adresem autokefalistów, których obwiniano w profanacji i dyskredytacji Cerkwi prawosławnej. Zwolenników autokefalii nie tylko wyzywano od „satanistów” i „bezbożników", lecz również porównywano do bolszewików. Autokefalię odbierano jako zdradę jedności duchowej i kanonicznej białoruskiego prawosławia z Rosyjską Cerkwią Prawosławną. W związku z powyższym wszelkie działania na rzecz autokefalii traktowano jako grzech przeciwko Kościołowi Chrześcijańskiemu ${ }^{17}$. W 1948 i 1949 na łamach czasopisma wszczęto zmasowaną akcję wymierzoną przeciwko BACP. Szczyt krytyki pod adresem „autokefalistów” przypada na rok 1949, kiedy to hierarchowie rosyjscy usiłowali doprowadzić do unieważnie-

\footnotetext{
${ }^{15}$ Православные - Белоруссы!!, s. 1.

${ }^{16}$ Протест, «Православный Белорусс» 1949, № 8, с. 3.

17 Декларация, «Православный Белорусс» 1949, № 9, с. 9.
} 
nia postanowień soboru założycielskiego BACP w Konstancji. Chirotonię biskupów i kleru BACP określano mianem ,prowokacji krywickiej” i „bluźnierstwem religijnym” ${ }^{18}$. Metropolia białoruska Rosyjskiej Cerkwi Prawosławnej za Granicą uważała się za jedyną prawowitą formę białoruskiego Kościoła prawosławnego na emigracji. W istocie stanowisko takie wobec autokefalii było odzwierciedleniem ogólnej polityki Rosyjskiej Prawosławnej Cerkwi za Granicą w stosunku do kościołów narodowych, które w XX wieku wyodrębniły się z patriarchatu moskiewskiego. Duchowieństwo rosyjskie na emigracji usiłowało za wszelką cenę zapobiec powstaniu nowych organizacji kościelnych Ukraińców i Białorusinów. Sądzono, iż dzielenie Rosyjskiej Cerkwi Prawosławnej na kościoły narodowe przyczyni się do osłabienia frontu antykomunistycznego emigrantów. W związku z powyższym nie tylko kwestionowano - zresztą nie bez racji - kanoniczność UACP i BACP, lecz również podważano uprawienia jej hierarchów do wykonywania posługi kapłańskiej.

Na łamach periodyku nie zabrakło również akcentów antypolskich. Tak na przykład „krywiczom” zarzucano zawarcie tajnej umowy z rządem polskim ma uchodźstwie, na mocy którego Białoruś miała wejść w skład „Rzeczypospolitej od morza do morza”, w której miało nie być miejsca dla cerkwi prawosławnej, a jedynie kościoła unickiego ${ }^{19}$. Rzym oskarżano o poparcie ,szowinistycznych” ruchów antyrosyjskich w celu osłabienia prawosławia. „Krywiczów” porównywano do ,polsko-litewskich jezuitów”. Do ,pechowych” wydarzeń w dziejach Białorusi zaliczano m.in. unię lubelską 1569 roku, która, zdaniem autorów, zmieniła życie Białorusinów ,jak w czasach Stalina”. Szkalowano wszystkich, którzy działali przeciwko caratowi rosyjskiemu (m.in. Ignacy Hryniewicki, Konstanty Kalinowski) ${ }^{20}$. Na łamach czasopisma «Праваслаўны

${ }^{18}$ Новая сектантская группировка в Белорусской ичеркви на эмиграцчи, «Православный Белорусс» 1951, № 13, с. 8.

${ }^{19}$ Самосвяты прокляты, «Православный Белорусс» 1949, № 8, с. 5.

${ }^{20}$ Краткие заметки, «Православный Белорусс» 1950, № 11, с. 44. 
беларус» zamieszczano teksty o treści antyunickiej, autorzy których szydzili z przedsięwzięć działaczy białoruskich zmierzających do szerzenia wśród dipisów idei Kościoła greckokatolickiego. Metropolia zajęła bardzo ujemne stanowisko wobec współpracy emigrantów białoruskich z czynnikami watykańskimi. Zwrócono uwagę na działalność koła studentów Białorusinów na Uniwersytecie Katolickim w Leuven. Udzielenie przez Watykan stypendiów dla młodzieży białoruskiej odbierano jako próbę nawrócenia jej na unię. Winę za to obarczano prezydenta Abramczyka i misjonarza katolickiego Roberta van Covaderta ${ }^{21}$. $\mathrm{Z}$ zasadzie akcenty antykatolickie uwidoczniały się tylko w kontekście nawracania prawosławnych. Sądzono, iż Stolica Apostolska popiera niepodległościowców białoruskich, usiłując wykorzystać ich do własnych celów misyjnych wśród prawosławnych Białorusinów ${ }^{22}$.

Mówiąc o białoruskiej prasie religijnej w Niemczech w omawianym okresie, należy również wspomnieć o jeszcze jednym wydaniu. W grudniu 1948 r. w Bawarii został wydany pierwszy numer czasopisma «Сіла веры» (Siła wiary). Wydawcą było Bractwo Ikony Matki Bożej Żyrowickiej, które zawiązało się w 1948 r. i zrzeszało w swoich szeregach duchowych i osoby świeckie należące do zwolenników świeżo utworzonej Białoruskiej Autokefalicznej Cerkwi Prawosławnej. Redaktorem naczelnym został Aleś Asipčyk, znany działacz prawosławny na uchodźstwie spod znaku BACР. Pierwsze numery czasopisma «Сіла веры» ukazały się w Niemczech, następne zaś były wydawane w latach pięćdziesiątych w Stanach Zjednoczonych, dokąd wyemigrował Asipčyk. Na łamach czasopisma dużo miejsca poświęcano zagadnieniom cerkiewnym (dogmaty, historia Cerkwi wschodniej) ze szczególnym uwzględnieniem relacji prawosławnych z innymi wyznaniami religijnymi ${ }^{23}$. Tak na przykład poruszano m.in. kwestie unii kościelnej, której

${ }^{21}$ О духовном окормлении лии, живущчих далеко от изеркви, «Православный Белорусс» 1950, № 12, с. 26-27.

${ }^{22}$ Краткие заметки, «Православный Белорусс» 1950, № 11, с. 49.

${ }^{23}$ Ад рэдакцылі «Сіла Верыл», «Сіла Веры» 1951, № 4, с. 1-3; Хрыстова Царква на Зямлі, «Сіла Веры» 1951, № 4, с. 1-3. 
skutki dla narodu białoruskiego oceniano negatywnie ${ }^{24}$. Nie brakowało jednak materiałów na temat bieżącej sytuacji prawosławnych emigrantów białoruskich. Periodyk jest znakomitym źródłem do historii BACP na uchodźstwie i Bractwa Ikony Żyrowickiej Matki Bożej. Jako zdeklarowani obrońcy autokefalii Cerkwi białoruskiej wydawcy potępiali przejście biskupów w jurysdykcję rosyjską i bronili poglądu o słuszności istnienia Białoruskiej Autokefalicznej Cerkwi Prawosławnej. Działania duchowieństwa rosyjskiego względem Białorusinów określano jako „imperialne” i „zaborcze”25. Publikacje zamieszczane na łamach czasopisma były przepojone fascynacją kulturą prawosławną. Podkreślano chrześcijańskie korzenia ruchu białoruskiego i odwieczne więzi kultury białoruskiej z wiarą prawosławną. Postulowano prawo Białorusinów do posiadania Cerkwi niezależnej od Moskwy i Warszawy. Promowano również wartości moralności chrześcijańskiej oraz zachęcano czytelników do pielęgnowania tradycji religijnych i narodowych na emigracji. Na łamach czasopisma publikowano także artykuły na temat historii białoruskiego prawosławia i jego wybitnych postaci. Pisano o świętych białoruskich oraz relikwiach, szczególną zaś czczą otaczano ikonę Matki Bożej w Żyrowicach ${ }^{26}$.

Porównanie treści trzech wspomnianych wyżej czasopism prawosławnych wskazuje na istnienie odmiennych tradycji w spojrzeniu na historię i kulturę białoruską. Omawiane czasopisma w zgoła inny sposób postrzegały zarówno historię Cerkwi na Białorusi, jak i wizję przyszłych relacji pomiędzy państwem i religią. Czasopismo «Зьвіняць званы Сьвятой Сафіi» cechował wysoki poziom merytoryczny zamieszczanych materiałów, rzetelna ocena faktów, staranny dobór artykułów. Czasopismo promowało koncepcję białoruskiego prawosławia i jego białoruskiego charakteru narodowego. Zbieżne stanowisko pre-

${ }^{24}$ «Праўда иі сьведамая брахня», «Сіла Веры» 1950, № 3, с. 26-27.

${ }^{25}$ У зарубежжы расейскага імпэрыялізму... і мы, «Сіла Веры» 1951, № 4, с. 9.

${ }^{26}$ Вялікія людзі уу нашай гісторыi, «Сіла Веры» 1949, № 2, с. 15-18; Сьвятыя Беларускай Зямлі, «Сіла Веры» 1949, № 2, с. 19-23. 
zentowała «Сіла Веры», aczkolwiek jej poziom i jakość publikowanych materiałów nie dorównywały poziomowi periodyku wydawanego przez Jurkę Vićbiča. Tymczasem wydawcom i autorom miesięcznika «Пpaваслаўны беларус» obce były jakiekolwiek białoruskie wartości narodowe. W zasadzie pismo powstało jako narzędzie propagandy na rzecz biskupów, którzy dołączyli do Cerkwi rosyjskiej. Nieprzypadkowo na łamach tego czasopisma roiło się od obelg i kpin wymierzonych nie tyle przeciwko adwersarzom ideologicznym lub politycznym, lecz przeciwko tożsamości białoruskiej jako takiej. Autorzy dalecy byli od przestrzegania zasad rzetelności w prezentowaniu faktów i wydarzeń.

Drugą co do liczebności po prawosławnych grupę wyznaniową wśród emigrantów białoruskich stanowili wyznawcy katolicyzmu (ok. 20\%). Po II wojnie światowej w Niemczech znalazło się kilku działaczy białoruskich wyznania katolickiego, którzy wywodzili się z przedwojennej chadecji białoruskiej w Polsce. Właśnie na nich spoczął ciężar wydania prasy o charakterze religijnym ${ }^{27}$. Pewne wyobrażenia na temat składu wyznaniowego dipisów białoruskich dają dane statystyczne dotyczące najliczniejszego obozu białoruskiego w miejscowości Watenstedt. Wolno sądzić, że na 1420 mieszkańców obozu przypadało zaledwie ponad stu katolików ${ }^{28}$. Bez względu na to, białoruscy działacze katoliccy wykazywali wiele energii i aktywności w dążeniu do utworzenia własnego duszpasterstwa. Po zakończeniu II wojny światowej w Niemczech zabrakło duchownych wyznania katolickiego narodowości białoruskiej. W brytyjskiej strefie okupacji działał ks. Michał Maskalik ${ }^{29}$,

${ }^{27}$ Historia białoruskiego ruchu katolickiego w powojennych Niemczech już stanowił przedmiot naszych rozważań: M. Jałoza, Życie religijne uchodźców białoruskich wyznania katolickiego w Niemczech Zachodnich w latach 1945-1951, „Studia Interkulturowe Europy Środkowo-Wschodniej” 2011, t. 6, s. 25-39.

${ }^{28}$ Беларуская бібліятэка і музей імя Францішка Скарыны ў Лондане (ББМФС), калекцыя а. Льва Гарошкі, імянны спіс беларусаў-каталікоў у лагеры Ватэнштэт.

${ }^{29}$ M. Maskalik, 18.3.1903, Horodziej (pow. nowogródzki) - 25.9.1965, FRN. W okresie międzywojennym studiował na Uniwersytecie Stefana Batorego w Wilnie i Wyższej Szkole Technicznej w Berlinie. Absolwent Uniwersytetu Maksymiliana w Monachium (1938). Beneficjent stypendium metropolity Andrzeja Szeptyckiego. 
ksiądz katolicki obrządku wschodniego, który pełnił funkcje dziekana dla dipisów Ukraińców. Ks. Moskalik dał się poznać jako gorliwy zwolennik utworzenia białoruskiej organizacji katolickiej wśród dipisów. W jednej z ulotek do katolików białoruskich w Niemczech duchowny pisał m.in.: „Sądzę, iż nadeszła już ta chwila, gdy my, katolicy białoruscy, powinniśmy zerwać te kajdany, które zmuszały nas do modlenia się w obcym języku. Musimy więc wziąć w swoje ręce sprawę Białoruskiego Kościoła katolickiego. Trzeba, żeby wszędzie, gdzie są pobożni Białorusini nabożeństwa celebrowali nasi duchowni, zaś język białoruski znowu zajął swoje poczesne miejsce w świątyniach białoruskich"30.

Duchowny ten miał jednak bardzo ograniczone możliwości działania na rzecz swych rodaków, gdyż był przydzielony do Ukraińskiego Kościoła grecko-katolickiego. Na zaproszenie działaczy białoruskich odprawiał on nabożeństwa dla uchodźców białoruskich ${ }^{31} .28$ stycznia 1947 r. grupa katolików obozu Watenstedt zwróciła się z listem do papieża z prośbą o przyjście im z pomocą. W liście tym zaznaczano, iż na skutek II wojny światowej tysiące Białorusinów-katolików znalazło się na obczyźnie, w obozach DP, gdzie pozbawieni są własnego duszpasterstwa i własnych świątyń. Zdaniem autorów tego listu taki stan rzeczy wynikał z faktu, że w okresie przedwojennym władze polskie zwalczały wszelkie przejawy białorutenizacji kościoła katolickiego. Autorzy podkreślali, że brak duchowieństwa białoruskiego sprawia, że wśród ludności białoruskiej na uchodźstwie szerzy się działalność sekt. Po zaprezentowaniu ciężkiej sytuacji dipisów narodowości białoruskiej wyznania katolickiego memoriał zawierał szereg próśb do Stolicy Apostolskiej. Po pierwsze, proszono o sprowadzenie do Niemiec „rozproszonych po całym świecie" księży białoruskich. Postulowano również

W 1939-1943 jako duchowny greckokatolicki przebywał w Niemczech. W 1943 r. został aresztowany i osadzony w obozie koncentracyjnym w Sachsenhausen. Po wojnie mieszkał w FRN. Działał w organizacjach białoruskich.

${ }^{30}$ ББМФС, калекцыя а. Л. Гарошкі, зварот кс. М. Маскаліка «Беларускі каталіцкі касцёл у Нямеччыне», б. д.

${ }^{31}$ А. Вініцкі, op. cit., с. 102. 
konieczność tworzenia w obozach DP białoruskich parafii katolickich, które stałyby się czynnikiem integrującym katolików-Białorusinów. Apelowano także o pomoc w organizacji i wydaniu prasy katolickiej w języku białoruskim. Żądano wydania czasopisma białoruskiego, które docierałoby do Białorusinów wyznania katolickiego na całym świecie ${ }^{32}$.

Przełomowym dla dipisów białoruskich wyznania katolickiego okazał się rok 1947. Pod koniec marca 1947 r. w Watenstedt powstała parafia katolicka, która liczyła blisko 120 wiernych. Druga parafia powstała w Windischbergerdorf ${ }^{33}$. 10 lipca 1947 r. przez papieża została powołana do istnienia Pontyfikalna Komisja Emigracyjna mająca na celu wspomagać uchodźców w obozach w Niemczech. W obrębie komisji powstawały komitety tworzone według klucza narodowościowego. W porozumieniu z władzami IRO 15 lipca 1947 r. powstał Białoruski Emigracyjny Komitet Watykański z ks. M. Maskalikiem na czele, który jednocześnie pełnił funkcję dziekana komitetu. Podjęto starania w kierunku tworzenia komitetów parafialnych. Te ostanie miały się składać z proboszcza i trzech osób przez niego wytypowanych. Komitet stawiał sobie za cel m.in. niesienie pomocy wiernym $\mathrm{w}$ przeprowadzkach do innych krajów (w państwach docelowego wyjazdu emigrantów, w Ameryce i Azji, istniały odpowiednie komitety watykańskie). Siedzibą centrali komitetu było Monachium. Poza tym istniały komitety parafialne w Goslar, Watenstedt (Branisłaŭ Daniłovič), Michelsdorf (Francišak Kušal), Windischbergerdorf (Andrej Papko) i Osterhofen (ks. J. Čarnecki $)^{34}$. Trzeba przyznać, że utworzenie komitetu nie spotkało się z uznaniem i aprobatą wielu działaczy białoruskich, którzy upatrywali w nim zjawisko szkodliwe białoruskiej idei narodowej. Uważano, że komitet przyczyni się do dzielenia Białorusinów według przynależności religijnej. Najwięcej zastrzeżeń budził główny cel komitetu, a mianowicie

${ }^{32}$ ББМФС, калекцыя а. Л. Гарошкі, зварот да Папы Рымскага, 28 студзеня 1947 г.

${ }^{33}$ А. Вініцкі, op. cit., с. 102.

${ }^{34}$ ББМФС, калекцыя а. Л. Гарошкі, «Урадавы весьнік» 1947, жнівень, с. 1-2. 
organizowanie wyjazdu katolików do innych państw i dążenie do tworzenia wspólnot katolickich dla Białorusinów ${ }^{35}$.

Katolicy białoruscy przystąpili do działalności wydawniczej. W marcu 1947 r. parafianie w obozie Windischbergerdorf zaczęli wydawać czasopismo „Adradžeńnie. Časapis biełarusaŭ katalikoŭ” (Odrodzenie. Czasopismo Białorusinów Katolików). Periodyk miał być miesięcznikiem, lecz w praktyce ukazywał się nieregularnie. Łącznie w okresie od marca 1947 do czerwca 1948 roku ukazało się sześć numerów pisma. Za główny cel redakcja stawiała sobie krzewienie wśród rodaków na emigracji idei moralnych i religijnych ${ }^{36}$. Periodyk przede wszystkim był skierowany do Białorusinów-katolików, lecz redakcja wyrażała nadzieję, że trafi on do serc Białorusinów niezależnie od wyznania religijnego. W pierwszym numerze redakcja zachęcała wszystkich uchodźców białoruskich do współpracy z czasopismem i nadsyłanie materiałów do druku (wierszy, opowieści, artykułów) ${ }^{37}$. Dużą wagę wydawcy przywiązywali do białorutenizacji życia kościelnego. Szczególnie postulowano potrzebę używania języka ojczystego w świątyniach katolickich. W jednym z artykułów czytamy: „Białorusini-katolicy! Już przyszedł czas, byśmy zerwali $\mathrm{z}$ resztkami zniewolenia psychicznego i w życiu religijnym zacząć używać języka ojczystego, białoruskiego"38. W związku z brakiem modlitewników w obozach na łamach czasopisma zamieszczano modlitwy oraz fragmenty Pisma Świętego w języku białoruskim. Publikowano również teksty o problematyce historycznej dotyczące historii Kościoła katolickiego na Białorusi. Twierdzono, że białoruski katolicyzm liczy aż 4 miliony ludzi. Podkreślano prawo Białorusinów do nadania katolicyzmowi cech narodowo białoruskich. Wydawcy i autorzy stanowczo sprzeciwiali się utożsamianiu katolicyzmu z polsko-

${ }^{35}$ А. Вініцкі, op. cit., с. 103.

${ }^{36}$ P. Dryhovič, Z błudnaje ściežki na pravilnuju darohu, „Adradžeńnie” 1948, nr 1, s. 9.

${ }^{37}$ Ad redakcyjnaje kalehii, „Adradžeńnie” 1947, nr 1, s. 1.

${ }^{38}$ J. Jiharovič, Za rodnuju movu ŭ žyćci religijnym i ŭ śviatyniach, „Adradžeńnie” 1947, nr 1, s. 4. 
ścią podważając stereotyp „Polak-katolik”. Jednocześnie uważano, że katolicy białoruscy nie powinni mieć żadnych kompleksów z powodu niedużej liczebności ${ }^{39}$. Autor artykułu „Narodowość zza Buga” zwracał uwagę na fakt, że na ziemiach białoruskich katolicyzm sprowadza się do ,polskiej religii" ${ }^{40}$.

$\mathrm{Na}$ łamach czasopisma starano się monitorować sytuację uchodźców, pisano o różnych sprawach mających związek z sytuacją emigrantów i ich życiem religijnym. Informowano np. o audiencji Białorusinów u papieża Piusa XII ${ }^{41}$. Odnoszono się również do stosunków katolików z przedstawicielami innych konfesji. Wydawcy bronili poglądu, że różnice wyznaniowe nie powinny dzielić Białorusinów. Nawoływano działaczy białoruskich, aby podnieśli się oni ponad podziały religijne. W związku z powyższym apelowano do rodaków, żeby przy zapisywaniu się do obozów narodowych nie kierowali się kryterium wyznaniowym, lecz tylko narodowościowym. Czasopismo miało regularną rubrykę „Z białoruskiego życia katolickiego”, w której zamieszczano informację o postępach w organizowaniu się uchodźców białoruskich wyznania katolickiego. Czasopismo ukazywało się w czasie, kiedy na obczyźnie powstawały zręby białoruskiego duszpasterstwa katolickiego. W związku z tym apelowano do czytelników o tworzenie parafii i komitetów parafialnych. Jednocześnie redakcja wyrażała żal z powodu tego, że organizacja białoruskiego duszpasterstwa katolickiego na obczyźnie postępuje w bardzo wolnym tempie ${ }^{42}$.

$\mathrm{Na}$ łamach czasopisma poruszano również kwestie polityczne i filozoficzne. Należy zaznaczyć, że niektórym autorom nie obce były poglądy fundamentalistyczne. Tak np. w artykule „Nasz Szlak” czytamy m.in.: „Ten, kto dziś otwarcie nie staje po stronie Chrześcijaństwa, ten świadomie lub nieświadomie służy bezbożnemu komuni-

${ }^{39}$ Ibidem, s. 3-4.

${ }^{40}$ P. Dryhovič, Nacyjanalnaść ,zza Buga”, „Adradžeńnie” 1948, nr 2-3, s. 17.

${ }^{41}$ Idem, Biełarusy ŭ śviatoha ajca, ,Adradžeńnie” 1947, nr 1, s. 2.

${ }^{42}$ Paŭła Uporysty, Treba nam katalickaja arhanizacyja, „Adradžeńnie” 1947, nr 1, s. 6-7. 
zmowi"43. Dużo miejsca poświęcano sprawom religijnym katolików innych narodowości niż białoruska, np. pisano o Ukraińskim Kościele Greckokatolickim i prześladowaniom jego wyznawców w Związku Sowieckim ${ }^{44}$. Ponadto na łamach czasopisma zamieszczano również artykuły poświęcone dziejom katolicyzmu na Białorusi. Zwracano uwagę na białoruskie korzenie obrządku łacińskiego na ziemiach Białorusi ${ }^{45}$. Nie należały do rzadkości także artykuły o katolicyzmie na Białorusi w okresie międzywojennym. Nie pominięto również problematyki związanej z innymi niż religia aspektami życia dipisów. W rubryce „Różne wieści” informowano czytelników o bieżących zmianach w organizacji i funkcjonowaniu obozów. Na uwagę zasługuje również to, że oprócz materiałów stricto religijnych i historycznych publikowano także utwory literackie (wiersze, eseje, opowieści).

Czasopismo „Adradžeńnie” nie było jedynym wydaniem katolików Białorusinów na ziemi niemieckiej. 6 kwietniu 1947 r. w Watenstedcie ukazał się pierwszy numer czasopisma „Biełaruskaja dumka” (Myśl Białoruska). Nazwą nawiązywano do gazety o tejże nazwie wydawanej w Wilnie w 1919 r. Był to drugi i ostatni periodyk katolicki wydawany przez emigrantów białoruskich w Niemczech w omawianym okresie. Wydawcą był Białoruski Katolicki Komitet Parafialny w Wattenstedt. Redaktorem naczelnym został Vacłaŭ Panucevič, znany działacz polityczny i religijny. Jest godne wzmiankowania to, iż w przeciwieństwie do „Adradžeńnia” wydawanego wyłącznie alfabetem łacińskim, „Biełaruskaja dumka" była drukowana zarówno cyrylicą, jak i łacinką. Od strony edytorskiej periodyk prezentował się znacznie lepiej niż „Adradžeńnie”. Na łamach czasopisma publikowano materiały dotyczące życia białoruskiego na obczyźnie ze szczególnym uwzględnieniem wydarzeń religijnych. Podobnie jak w przypadku „Adradžeńnia”, na łamach

\footnotetext{
${ }^{43}$ K. Stp., Naš Šlach, „Adradžeńnie” 1948, nr 1, s. 2.

${ }^{44}$ „Adradžeńnie” 1948, nr 2-3, s. 9-10.

${ }^{45}$ V. Horadzienski, Z historyji katalictwa $\breve{u}$ Biełarusi (Kryviji), „Adradžeńnie” 1947, nr 1, s. 7-8.
} 
czasopisma „Biełaruskaja dumka” pobrzmiewały apele do rodaków, by tworzyli białoruski Kościół katolicki na emigracji. Propagując ideę białorutenizacji życia religijnego, postulowano potrzebę „odpolszczenia” Kościoła katolickiego na Białorusi. Poruszano jednak tematy dotyczące bieżącej sytuacji dipisów. W jednym z artykułów pt. Przed emigracja nawoływano rodaków, by wykazywali większą aktywność w organizowaniu się w obliczu akcji przesiedleńczej z Niemiec do innych państw ${ }^{46}$. Autorzy podkreślali, że Białorusini wszystkich wyznań powinni trzymać się razem, a nie „błądzić po obcych kątach”. Redakcja sprzeciwiała się faworyzowaniu jakiejkolwiek religii i opowiadała się za poszanowaniem każdej, która ma pozytywny stosunek do białoruskich interesów narodowych ${ }^{47}$. Na tym tle redakcja weszła w spór ze wspomnianym wcześniej czasopismem prawosławnych Białorusinów «Зьвіняць званы Сьвятой Сафіi», zarzucając wydawcom tego periodyku stronniczość w postrzeganiu stosunków prawosławno-katolickich na Białorusi oraz publikację materiałów obrażających uczucia katolików Białorusinów. Chodziło o ocenę unii brzeskiej i jej wpływ na Białorusinów ${ }^{48}$. W dziale „Z całego świata” zamieszczano informacje na temat polityki i religii w poszczególnych krajach. Redakcja współpracowała z organizacjami innych narodowości, np. nawiązano kontakt z Litewską Służbą Bibliograficzną ${ }^{49}$.

Oprócz wspomnianych wyżej tytułów prasowych katolicy białoruscy wydali również kilka jednodniówek. W jednej z nich zatytułowanej «Наш уклад» podkreślano, że duchowni katoliccy i działacze świeccy wyznania katolickiego na równi z przedstawicielami innych wyznań są zasłużeni dla spawy białoruskiej ${ }^{50}$.

Część dipisów narodowości białoruskiej stanowili protestanci. Począwszy od drugiej połowy lat czterdziestych, wśród emigrantów tego

\footnotetext{
${ }^{46}$ V. Jastrab, Pierad Emihracyjaj, ,Biełaruskaja dumka” 1947, nr 2, s. 2.

${ }^{47}$ Дзьве рэлігіi, „Biełaruskaja dumka” 1947, nr 2, s. 3.

48 «Зьвіняцьь звань Сьвятой Сафіi», „Biełaruskaja dumka” 1947, nr 2, s. 4.

${ }^{49}$ А. Вініцкі, op. cit., с. 102.

${ }^{50}$ ББМФС, калекцыя а. Л. Гарошкі, лістоўка «Наш уклад», б. д.
} 
wyznania ożywił się ruch organizacyjny. Wśród najbardziej aktywnych działaczy tego ruchu należy wymienić m.in. A. Husarčyka, V. Aleksandruka i N. Lisoŭskiego ${ }^{51}$. Protestanci białoruscy na emigracji również zdawali sobie sprawę z potrzeby posiadania własnego słowa drukowanego. Białorusini wspierani byli przez ich współwyznawców innych narodowości. 11 września 1947 r. w Hanowerze na posiedzeniu Komitetu Słowiańskiego Związku Kościołów Ewangelistów-Baptystów zapadła decyzja w sprawie wydania biuletynu informacyjnego w czterech językach, w tym w białoruskim. 5 lutego 1948 r. na kolejnym posiedzeniu postanowiono wydawać czasopismo «Паведамленьні» (Wiadomości), którego wydanie z przyczyn technicznych nie zostało zrealizowane. 10 lutego 1949 r. podczas posiedzenia komitetu wydanie prasy ewangelickiej dla Białorusinów powierzono Dymitrowi Jaśko. Za sprawą tego działacza w Stuttgarcie zaczęto wydawać czasopismo «Слова пацяшэньня» (Stowo pocieszenia). Pierwszy numer tego czasopisma dla Białorusinów-baptystów ukazał się w kwietniu 1949 r. Wydanie uważano za kontynuację przedwojennej białoruskiej prasy protestanckiej. Na łamach periodyku przeważały artykuły o treści religijnej, nie poruszano natomiast spraw organizacyjnych lub społecznych ${ }^{52}$.

Bez względu na różnice wyznaniowe wszyscy wydawcy białoruscy w Niemczech uporali się z wieloma problemami natury materialnej, co miało wpływ na jakość wydawnictw. Wydawcy borykali się z trudnościami materialnymi i brakiem środków. Wygląd zewnętrzny tych czasopism pozostawiał dużo do życzenia, bowiem drukowano je za pomocą powielaczy. Do produkcji wykorzystywano papier o niskiej jakości. Pamiętajmy, że w większości przypadków czasopisma wydawane były wyłącznie dzięki zaangażowaniu i pracy poszczególnych działaczy, którzy w zasadzie nie korzystali z pomocy zewnętrznej. Wszystkie periodyki były wydawane na zasadzie rękopisów, ponieważ wydawa-

${ }^{51}$ J. Garbiński, J. Turonek, Białoruski ruch chrześcijański. Słownik biograficzno-bibliograficzny, Warszawa 2003, s. LXX.

${ }^{52}$ Слова пацящэньня, «Слова пацяшэньня» 1949, № 1, с. 19-20. 
nie prasy wymagało odpowiedniego pozwolenia władz alianckich. Co prawda, w październiku 1946 r. alianci przyznali poszczególnym grupom narodowościowym prawo do posiadania własnej prasy (nie więcej niż 4 gazety i 2 czasopisma). Otrzymanie licencji ułatwiało pracę nad wydaniem tytułu, gdyż władze UNRRA przewidywały wsparcie finansowe i techniczne. Nie dotyczyło to jednak wspomnianych czasopism religijnych. W związku z powyższym ich nakład nie przekraczał stu egzemplarzy, zaś ich wydanie miało charakter półlegalny. Warto również pamiętać, że wydanie tej prasy nie było głównym zajęciem ludzi, którzy ją wydawali. Zazwyczaj robiono to w wolnym od pracy czasie, bez fachowego przygotowania i niezbędnych do tego środków technicznych. Wszystkie wydawnictwa były rozpowszechniane wśród dipisów: zwykle rozsyłano pocztą do głównych skupisk emigrantów. Wydawcy dbali również o to, by ich prasa docierała do rodaków rozsianych po świecie, więc niektóre numery były wysyłane do ośrodków życia białoruskiego na Zachodzie. Niewątpliwie prasa ta nosiła na sobie piętno czasu, w którym powstała. Wydawcom nie udało się uniknąć wciągnięcia w wir sporów toczonych wśród emigrantów. Przede wszystkim chodziło o podział na „Krywiczów” i ,zarubieżników” będących nie tyle pokłosiem różnic ideologicznych, ile ambicji poszczególnych przywódców emigracyjnych. W związku z tym intencją wydawców było m.in. pozyskanie rodaków i przekonanie ich do własnych racji. Białoruska prasa religijna stanowi niezwykle cenne źródło dotyczące historii emigracji białoruskiej po II wojnie światowej, nie tylko religijnej. Brak stosownych źródeł nie pozwala udzielić odpowiedzi na wiele interesujących pytań związanych $\mathrm{z}$ historią białoruskiej prasy religijnej w omawianym okresie. Jest jednak pewne, że znikomy nakład oraz trudności z kolportażem uniemożliwiały dostęp do nich szerokiej rzeszy emigrantów.

Do 1951 r. wszystkie obozy DP w Niemczech, w tym także białoruskie, zostały rozwiązane, a ich mieszkańcy wyemigrowali do innych państw zachodnioeuropejskich, obu Ameryk i Australii. W dziejach powojennego uchodźstwa białoruskiego dobiegł końca bardzo ważny i burzliwy etap. Na nowym miejscu kontynuowano działalność kultu- 
ralno-oświatową i religijną. Wydawano tam również prasę o charakterze religijnym. Działo się tak m.in. we Francji, Stanach Zjednoczonych, Anglii. Problem ten wymaga jednak osobnego studium.

\section{Źródła archiwalne}

Instytut Polski i Muzeum im. gen. Sikorskiego, Białoruskie uchodźstwo niepodległościowe, sygn.: A.11E.1110.

Беларуская бібліятэка і музей імя Францішка Скарыны ў Лондане, калекцыя а. Льва Гарошкі.

\section{Bibliografia}

„Adradžeńnie” 1948, nr 2-3.

Ad redakcyjnaje kalehii, „Adradžeńnie” 1947, nr 1.

Dryhovič P., Biełarusy ǔ śviatoha ajca, „Adradžeńnie” 1947, nr 1.

Dryhovič P., Nacyjanalnaść „,zza Buga”, „Adradžeńnie” 1948, nr 2-3.

Dryhovič P., Z błudnaje ściežki na pravilnuju darohu, „Adradžeńnie” 1948, nr 1.

Garbiński J., Turonek J., Białoruski ruch chrześcijański. Stownik biograficzno-bibliograficzny, Warszawa 2003.

Grzybowski J., Grzybowska M., Białoruska Autokefaliczna Cerkiew Prawosławna na emigracji i udział w jej działalności duchowieństwa ukraińskiego, «Наукові записки Національного університету „Острозька академія”. Серія „Історічні науки”» 2013, вип. 20.

Grzybowski J., Pogoń miedzy Ortem Białym, Swastyka i Czerwona Gwiazda. Biatoruski ruch niepodległościowy w latach 1939-1956, Warszawa 2011.

Horadzienski V., Z historyji katalictwa ŭ Biełarusi (Kryviji), „Adradžeńnie” 1947, nr 1 .

Jałoza M., Życie religijne uchodźców białoruskich wyznania katolickiego w Niemczech Zachodnich w latach 1945-1951, „Studia Interkulturowe Europy Środkowo-Wschodniej" 2011, t. 6.

Jastrab V., Pierad Emihracyjaj, „Biełaruskaja dumka” 1947, nr 2.

Jiharovič J., Za rodnuju movu ŭ žyćci religijnym i ŭ śviatyniach, „Adradžeńnie” 1947, $\mathrm{nr} 1$.

K. Stp., Naš Šlach, „Adradžeńnie” 1948, nr 1.

Paŭła Uporysty, Treba nam katalickaja arhanizacyja, „Adradžeńnie” 1947, nr 1. Ад рэдакиылі «Сіла Веры», «Сіла Веры» 1951, № 4. 
Белорусские остарбайтеры. Историко-аналитическое исследование, Минск 2001.

В-а, Беларуская Праваслаўная Царква павінна быщь наџылянальнай, «Зьвіняць званы Сьвятой Сафіi» 1946, № 3.

В-а, Царква і Народ, «Зьвіняць званы Сьвятой Сафіi» 1946, № 3.

Вініцкі А., Матэрыяль да гісторыі беларускай эміграцыі у Нямеччыне у 1939-1951 гадох. Ч. 2. Рэлігійныл справы, Los Angeles 1968.

Вялікія людзі ў нашай гісторыi, «Сіла Веры» 1949, № 2.

Гарбінскі Ю., Беларускі рэлігійны друк на Захадзе, 1945-2005, New York, Warszawa 2009.

Гардзіенка Н., Беларусы у Вялікабрытаніi, Мінск 2010.

Декларачия, «Православный Белорусс» 1949, № 9.

Дзьве рэлігіi, „Biełaruskaja dumka” 1947, nr 2.

Долой ненавистное знамя "Погоня», Да здравствует наме славное белое со св. Георгием Победоносием белорусское знамя, «Православный Белорусс» 1949, № 10.

Зварот беларускай грамадзкасьиі да беларускага епіскапату, «Зьвіняць званы Сьвятой Сафіi» 1946, № 4.

«Зьвіняць званы Сьвятой Сафіi», „Biełaruskaja dumka” 1947, nr 2.

Краткие заметки, «Православный Белорусс» 1950, № 11.

Крыжаніч А., Гара нарадзіла мыли, «Зьвіняць званы Сьвятой Сафіi» 1946, № 4.

Максімюк Я., Беларуская гімназія імя Янкі Купаль ў Заходняй Нямеччыне 1945-1950, New York, Białystok 1994.

Новая сектантская группировка в Белорусской церкви на эмиграџии, «Православный Белорусс» 1951, № 13.

О духовном окормлении лии, живущих далеко от иеркви, «Православный Белорусс» 1950, № 12.

Православные - Белоруссы!! «Православный Белорусс» 1949, № 8.

«Праўда иі сьведамая брахня», «Сіла Веры» 1950, № 3.

Протест, «Православный Белорусс» 1949, № 8.

Самосвяты прокляты, «Православный Белорусс» 1949, № 8.

Селянін, У Беларускім Праваслаўным Аб’яднаньні, «Зьвіняць званы Сьвятой Caфii» 1946, № 6 .

Слова пачяшэньня, «Слова пацяшэньня» 1949, № 1.

Сьвятыя Беларускай Зямлі, «Сіла Веры» 1949, № 2.

У зарубежжы расейскага імпэрыялізму... і мыл, «Сіла Веры» 1951, № 4.

Хрыстова Царква на Зямлі, «Сіла Веры» 1951, № 4. 


\section{Belarusian religious press in West Germany 1945-1951}

The article is about the Belarusian religious press (Orthodox, Catholic, Protestant) published in the three Western German occupation zones in the first post-war years. At that time, the largest number of Belarusian war refugees lived in West Germany. An important element of the emigrants' life was religious activity, which included publishing. This activity had three main causes: social, political and national. It was an almost universal response by refugees in the face of an uncertain future. These people were deprived of their homeland, found themselves in an alien cultural environment without the possibility of influencing their own fate, completely at the mercy of others. In this situation, their sorrows, worries and anxieties were expressed on paper. Political dissension between post-war Belarusian emigrants contributed to the intensification of publishing activity. It initiated a heated polemic between supporters of two opposing camps: the Council of the Belarusian Democratic Republic and the Belarusian Central Council. Publishing activities also served to preserve the national identity of emigrants and propagate national and patriotic values among them (especially among young people).

Keyw ords: Belarusian diaspora, West Germany, religion, press 